\title{
POLISH LANGUAGE CATHOLIC PODCASTS AS A FORM OF RELIGIOUS COMMUNICATION Anna Gawrońska-Piotrowska
}

\begin{abstract}
Media are present today in many areas of human life, also in the sphere of faith. New ways of communicating of media content are emerging. Podcasts are an example of such a form. In this article, an attempt has been made to analyse radio podcasts concerning the faith as a form of religious communication. The aim of the research was to answer the question: Are radio podcasts concerning the topics of faith as a form of religious communication? If so, why and how do they do that? Additional questions were also established: What is religious communication? What are the characteristics of radio podcasts? What are the characteristics and content of the faith-themed podcasts? The concept of religious communication was defined in order to obtain answers to these questions. Then, the specificity of radio podcasts was shown, and, in the next part of the article, the author moved on to the identification and analysis of the content of popular Polish-language podcasts on the topics of faith.
\end{abstract}

Keywords: radio podcasts, faith, religious communication, podcasts in Poland

\section{Introduction}

The media today exert an enormous influence on social and public life, as well as on the lives of individuals, human behaviour and attitudes - including religious or moral attitudes. As early as 1992, the Pontifical Council for the Social Media stressed the enormous role of the media in the transmission of faith and Church teaching: "At the dawn of a new era, the scope for people to communicate with each other is expanding considerably, which is having a very profound effect on culture throughout the world. Technological breakthroughs are only one aspect of this phenomenon. There is no place today where the influence of the media on religious and moral attitudes, on political and social systems or education cannot be felt." [Pontifical Council for the Social Media, 1992, pp. 50-59].

Pope Benedict XVI, in his "Message for the 44th World Media Day" in 2010, perceived that: "The digital world, providing means that give almost unlimited capacity for expression, allows us to read Paul's call in a new way: 'Woe to me if I do not preach the Gospel"' (1 Cor 9:16). With the spread of new technologies, the duty to preach not only 
increases but also becomes more urgent, requiring a more motivated and affective commitment. The priest, therefore, finds himself, as it were, at the beginning of a 'new era', for the more modern technologies build ever closer relationships and the more the digital world expands its boundaries, the more he will have to take all this into account in his pastoral work, multiplying his commitment to using the media at the service of the Word" [Benedict XVI, 2010, p. 6].

As we can see, therefore, the Catholic Church sees a great and ever-growing need for evangelisation through social media. New technologies and the emergence of more and more modern forms of media is becoming a challenge in the field of research on their use to proclaim the Good News.

It is also worth emphasizing that the shaping of the media space - also that related to evangelization by the media - is influenced by the phenomenon of media convergence and blurring the boundaries between media genres. In general, media convergence refers to merging and interconnection of media content IT and telecommunications technologies [Dobrek-Ostrowska 2007, p. 77]. This phenomenon is crucial for understanding the essence of changes in the media [Jakubowicz 2011, p. 27]. From a technical point of view, convergence is a combination of various techniques of information processing and distribution [Jenkins 2006, p. 9]. A key element of convergence is the digitization process that helps to connect previously separate media platforms - print media (newspapers and magazines), telecommunications media (TV, radio, cable and satellite) and the internet. Due to digitization, technical and institutional constraints between different types of media have been overcome. This has led to reduction of production costs and distribution of media content, enabling recipients to find new ways of archiving, commenting and redistributing them. In the new media reality, the Internet has become a potential distribution channel for all media messages. As it was noted by A. Pawlik [2012, pp. 382-383], "the Internet is a capacious platform within which all existing media can function - television, radio, telephony, newspapers, books". The concept of podcasting is related to the functioning of audio and / or video files on the web. This article will analyse a new and increasingly popular form of Internet audio publication - radio podcasts that concerns the subject of faith as a form of religious communication.

The aim of the research is an attempt to answer the question: Are radio podcasts on the topics of faith a form of religious communication and why? To answer this question, additional auxiliary questions were established: What is religious communication? What are the characteristics of radio podcasts? What are the characteristics and content of the faith-themed podcasts discussed?

To answer the main research question and additional questions, the concept of religious communication will first be defined and its characteristics will be described. Then, the specifics of radio podcasts will be presented, and in the next part of the article, we will move on to identify and analyse the content of popular Polish-language podcasts about faith. These podcasts will be analysed in terms of the role they play in the context of religious communication. The author will also investigate how religious content is presented in studied podcasts.

\section{Religious communication in the media - an attempt at definition and characteri- sation}

Religious communication falls within the field of social communication [Marcyński, $2016 a$, p. 71]. The subject of religious communication is more and more often studied in Polish and foreign literature. The most significant works published so far on this topic concern, among other topics: the context of anthropological relativism and religious pluralism [Kim J., Kim C. 2016], Catholic media and their position on the media market in Poland [Adamski, Jupowicz-Ginalska, Leonowicz-Bukała 2020; Guzek 2016], the image of the Catholic Church in secular media [Guzek 2019], marketing communication of the 
Catholic Church [Gawroński, Majkowska 2018], mediatisation of religion [Hjarvard 2016], and the influence of markets and the media on the contemporary religious environment of major institutional Christian churches in the Western world [Moberg 2019].

It should be noted that religious communication is a quite ambiguous and not fully defined concept; however, both foreign and Polish researchers are trying to standardize the definition of this term. One of the definitions of this term is formulated by Father Krzysztof Marcyński, referring, among others, to the etymology of the term religious communication (Latin communication religious). He defines it as a kind of communication linking man with the Absolute, referring to the Absolute: [Marcyński, 2016a, p. 72]. Marcyński notes that like any communication, also religious communication has its form and content. And so the content can be created in this case: the Absolute itself, religious practices, and religious knowledge. The form is e.g. word, sound, silence, image, and symbol. Also important in religious communication are the media that enable the transmission of the message - e.g. print media, electronic media, mobile communication media, social media [Marcyński, 2016a, p. 72].

The researcher also devoted a book to religious communication Religious Communication and the Media, in which he examines this concept in depth. At the end of this publication, summarising his reflections on religious communication in the media, he notes: "The communication of Jesus of Nazareth is "more than the communication of ideas or the expression of feelings". It is, above all, 'giving oneself out of love'. This form and this style of communication are for the preaching of the Word of God the greatest and most innovative paradigm of religious communication" [Marcyński, 2016b, p. 159].

Another author, Rafal Jakub Pastwa, emphasises - regarding the new media as a platform for the exchange of knowledge about the views of faith and the Church - that "religious communication is in this sense an uninterrupted and permanent process, characterised however by variability and different levels of intensity" [Pastwa, 2020, p. 42]. He defines this concept as "the process of externalizing, presenting, as well as portraying religion as a reality capable of uniting persons within the area of the institution of the Church and based on the universal message of the Gospel" [Pastwa, 2020, p. 41]. According to Pastwa, the process of religious communication also includes the space and manner of contact of man with God, but also a man with another man, also through the media. He notes that often the form attracts more attention of the recipient than the content. Therefore, the form, quality and attractiveness of the message are so important in the process of religious communication [Pastwa, 2020, p. 44].

Media scholar, Rev. Rafal Lesniczak, presents the term of religious communication as "mediatised forms of social communication relating to people belonging to churches and other religious associations or addressing religious issues in their messages" [Lesniczak, 2018, p. 88]. So, he refers the term to a variety of faiths without limiting it to Christianity or Catholicism. As Lesniczak also notes, in some academic publications (e.g. La missione digitale - Comunicazione della Chiesa e social media [Tridente, Mastroianni, 2016] religious communication is interpreted as "exclusively an institutionalised form of communication carried out by representatives of the hierarchical church" [Lesniczak, 2018, p. 87].

The author of this article finds the definition of religious communication presented by Father Krzysztof Marcyński as the most precise. Namely, the author understands the term of religious communication as a special part of social communication, connecting a man with the Absolute or a man with a man to the Absolute.

\section{Radio podcasting - a conceptual framework and an attempt at description}

Radio podcasting is another key concept in the context of the considerations undertaken. Podcasting is a relatively new concept, having been present in the media for only a short time. The first use of the term 'podcasting' is attributed to The Guardian journalist 
Ben Hammersley in 2004. The term was created by combining the particle 'pod', derived from the name of a portable mp3 player - the iPod - and a part of the word 'broadcast', which is associated with radio transmission. It described the new phenomenon of producing and making available online audio content that can be subscribed to using special software [Bonini, 2015, pp. 21-30].

Researcher Kris M. Markman understands podcasting as "a method of delivering audio and/or video files via RSS (Really Simple Syndication) feeds that allow a given piece of content to be received in one place for download or playback on a variety of devices" [Markman, Sawyer, 2014, pp. 20-35]. It is worth noting that K.M. Markman limits podcasting to receiving files via RSS.

Grażyna Stachyra extends K.M. Markman's approach by adding that the recipient can both subscribe to and store podcasts. A computer, an $\mathrm{mp} 3$ player, and a mobile phone can be used for this types of files. Podcasts can also be received, for example, as excerpts from broadcasts on radio stations' websites. They are naturally associated with a radio. They are considered a post-radio product, although this is often controversial. Stachyra also writes about the "relational" nature of this media form, which is related to the transmission of content with interactional and interactive potential [Stachyra, 2019, pp. 71-89]. The researcher in the article Podcasting as an audio technology [Stachyra, 2017, pp. 29-41] synthetically describes the history of the development of radio podcasting. She notes that in the initial phase of development, from 2004, podcasting was intended only to enrich the offer of radio stations by making excerpts of selected programmes available on their websites for free. Changes came after less than a decade. From 2012, podcasting started to turn into a profitable business. That's when the first social media platform called Kickstarter was created to fund podcasts. The best podcasts were able to migrate from the radio. They, thus, gained the conditions to exist without institutional constraints, relying on the contributions of listeners and sponsors to function directly. Thanks to this platform, for example, the podcast series on Latin America entitled Radio Ambulante and many other series were launched. The project Radiotopia by Roman Mars, among other things, featuring narrative podcasts, was also created here. For this purpose, US\$620,000 was raised in 2014. The guarantee of high revenues from fundraising for the creation of podcasts became the names of well-known journalists coming from public stations, who prepared podcasting series at a high level. They were sometimes called storytelling stars. Journalists such as Ira Glass, Sarah Koenig and Roman Mars are among the leaders of global podcasting. Stachyra also notes that the evolution of podcasting is happening in two streams: commercial and amateur (non-profit). And in addition to platforms that can generate revenue for established podcasters (e.g. PodcastOne or Midroll), hosts for novice podcasters are emerging (e.g. the Podbean-integrated audio platform Patreon, the podcast-related apps and ads of the BlogTalkRadio platform - where revenues fund podcasters' accounts) [Stachyra, 2017, pp. 29-31].

The creator of this media form, Igor Podgórski, characterises podcasts in the trade press interestingly, comparing them to the radio itself: "This form of information transmission is developing more and more dynamically, primarily due to the comfort of the recipient in receiving content presented in this way. The message in this form may be received during many other activities, even while driving a car. [There are two major differences between podcasting and radio - the form of transmission and the form of consumption. Radio is most often broadcast live, whereas a podcast is a recording published on the internet (just like a video on YouTube), which is always available and you listen to it when you feel like it. In addition, a podcast is usually themed and episodic, with each episode lasting from several minutes to as much as 2 hours. Radio, on the other hand, is broadcast for most of the day, is rarely based on a specific topic (because it contains segments based on different topics) and often plays music" [Podgórski, 2021]. Elsewhere, Podgórski points to streaming platforms popular in Poland:

- Spotify, 
- Apple Podcasts (formerly iTunes),

- Google Podcasts,

- Soundcloud.

He also mentions podcast creators' websites with an embedded audio player and YouTube - which is a channel for receiving both video content and the audio itself. Podgórski also notes that podcasts sometimes come in video form. This is known as a videocast - that is, a file that remains a podcast but offers a vision in addition. So the viewer sees people talking to each other [Podgórski, 2021].

The authors of the article Podcasting in Poland - an attempt to analyse the phenomenon [Doliwa, Chyczewska, Grobelski, Łatacz, 2019, p. 38] rightly note that: "Podcasting is increasingly diverse, both in terms of form, subject matter, but also in terms of the level of professionalism or motivations accompanying the creators. It is also one of the fastest-growing media segments among audiences according to research by Tandem Media $^{2}$. The report shows that almost every third Polish Internet user regularly listens to podcasts. The monthly reach of this media form in Poland recorded an increase from $27 \%$ in 2019 to $31 \%$ in 2020 (Figure 1). "The popularity of podcasts is determined by many factors. The most important certainly include the constant access of Poles to the internet and the widespread 'smartphoneisation'" - reads Maciej Kozielski's article on the Press.pl portal [Press.pl, 2021].

\begin{tabular}{|l|l|l|}
\hline \multirow{2}{*}{ How big is the market? } & $\mathbf{9} \mathbf{m l n}$ & listeners \\
\cline { 2 - 3 } & $\mathbf{3 1 \%}$ & Internet users in Poland \\
\hline \multirow{3}{*}{ How do you reach podcasts? } & $\mathbf{8 1 \%}$ & at home \\
\cline { 2 - 3 } & $\mathbf{4 7 \%}$ & on smartphone \\
\cline { 2 - 3 } & $\mathbf{2 6 \%}$ & on laptop \\
\hline \multirow{3}{*}{ Facts about podcast listeners } & $\mathbf{6 5 \%}$ & $\begin{array}{l}\text { users started listening to podscasts } \\
\text { during max one year before the research }\end{array}$ \\
\cline { 2 - 3 } & $\mathbf{4 4 \%}$ & $\begin{array}{l}\text { listen to podscasts more often than be- } \\
\text { fore }\end{array}$ \\
\cline { 2 - 3 } & $\mathbf{4 7 \%}$ & listeners have higher education \\
\hline & $\mathbf{5 7 \%}$ & listeners are 35+ \\
\hline
\end{tabular}

Figure 1. Information on podcast listeners in Poland in 2020 based on Tandem Media research from November 2020

Source: Press.co.uk, 2021.

Additionally, it is worth noting that according to a 2020 study by Voxnest, the number of podcast audiences worldwide is growing rapidly. Interestingly, according to this report, Poland is among the top countries where this growth is the fastest (Figure 2).

\begin{tabular}{|c|}
\hline Fastest growing podcast markets: \\
\hline Brasil \\
\hline Great Britain \\
\hline Canada \\
\hline Columbia \\
\hline Italy \\
\hline Mexico \\
\hline
\end{tabular}




\begin{tabular}{|c|}
\hline Spain \\
\hline Poland \\
\hline New Zealand \\
\hline USA \\
\hline
\end{tabular}

Figure 2. Fastest growing podcast markets globally according to Voxnest data from January to May 2020

Source: Majchrzyk, 2020.

The details of the growth in the number of viewers of this type of media form are reflected in Spotify's data from the first half of 2020. According to them, over 300 percent more hours of podcasts were listened to in Poland than in the same period last year.

Not only are podcasts increasingly listened to, but they are also increasingly diverse, touching on a wide range of topics. According to a November 2020 report by Tandem Media [Press.pl, 2021], the most listened to podcasts among audiences are those on the following topics: history and society, psychology, lifestyle, crime fiction, news and politics, music, and health. Earlier research from August 2019 [Mmponline.pl, 2019] further differentiates podcast topics into those most popular among women (here dominated by health and lifestyle, psychology, education and foreign languages, motivation, and development) and men (here popular topics include technology, history and society, business, marketing, as well as advertising and sport). Music and entertainment are at a similar, high level of listenership among both genders (Figure 3).

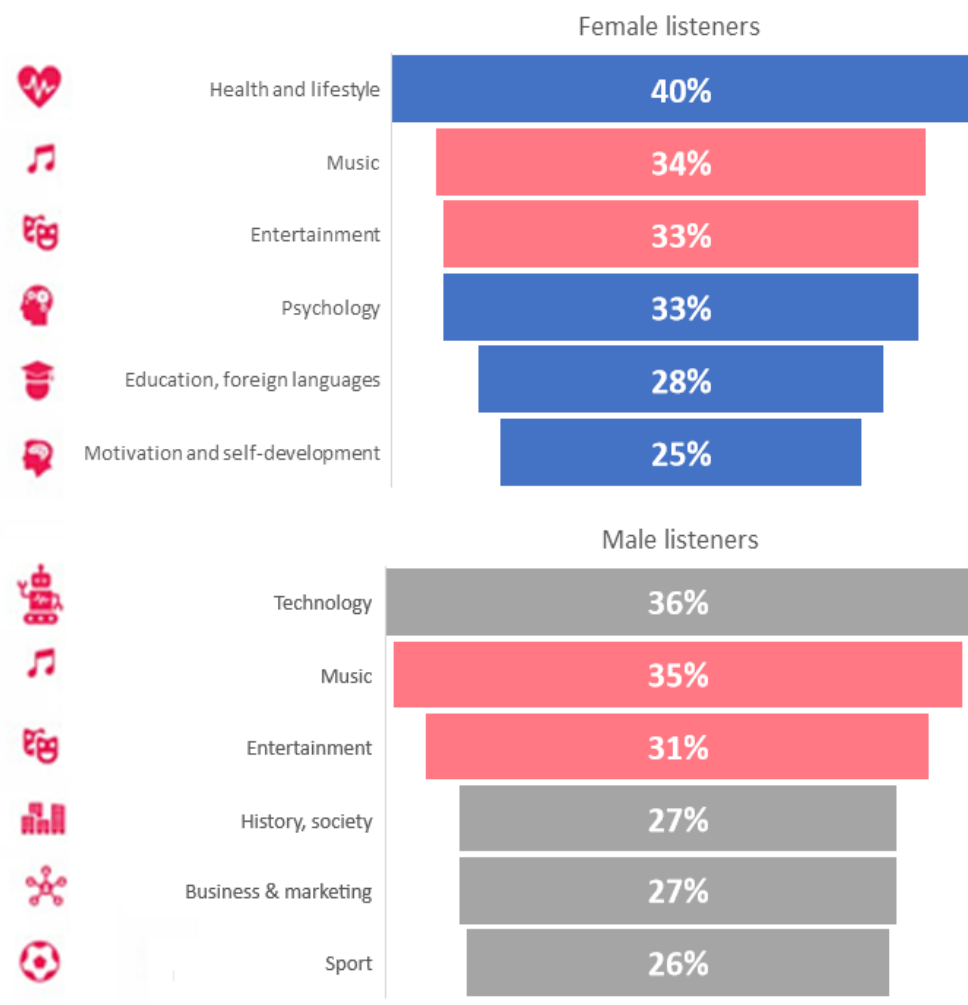

Figure 3. Podcast topics of greatest interest to listeners by gender - based on Tandem Media's August 2019 research (all 18+, $\mathrm{N}=1043$ )

Source: Mmponline.co.uk, 2019.

Religion is also one of the topics discussed in podcasts. The author devotes the next part of the article to this issue, addressing Catholic radio podcasts on the Polish market. 


\section{Selected Polish-language radio podcasts about faith - presentation and analysis}

This part of the dissertation presents thr selected Polish-language radio podcasts about faith. The author of the article narrows the research down to Catholic podcasts. These are both programmes produced by the clergy, church institutions and laypeople. The selected podcasts are described on the basis of an on an analysis of materials published on selected streaming platforms (Apple Podcasts, Spotify, Google Podcasts) and YouTube channels - conducted through individual listening - in the context of the research questions posed by the author.

The Pray-as-you-go podcast is about ten minutes of daily reflections combining verses from the Bible with music. The Polish Jesuits are responsible for their preparation, inspired by the example of their brothers in Great Britain, where the Pray-as-you-go project has over 300 thousand downloads of mp3 files a month. The content of the reflections differs each day, but the pattern of the podcasts is similar. Each recording contains the liturgical readings for the day, a commentary explaining the Word of God and some questions for the listeners to answer after individual reflection. As the creators of the podcast write: "Nowadays, many people spend a lot of time commuting to work or school. This is time that can be put to good use. [...] The idea that accompanied the development of the project was very simple: to find an answer to the rapid development of modern ways of communication that change our daily lives, and which also affect spiritual life. The proposal of short, accessible reflections on the Gospel is meant to meet the needs of modern man, who leads a very active, often busy lifestyle. When we invite Christ into all our activities, we will see that in every place He wants and can be with us". [Facebook, 2021b]. The recordings are prepared professionally in a recording studio; the commentaries are read by professional lectors. The editing of the podcasts is also on a very good technical level, along with the quality of the background music. Such attention to sound and technical values undoubtedly influences the easy and pleasant reception of recordings. Podcasts can be listened to via the platform: Spotify, Apple Podcasts, Google Podcasts, as well as on the website run by the Polish Jesuits - https:// modlitwawdrodze.pl/.

The Listening With the Heart podcast is a series prepared by Sister Anna Maria Pudełko of the Congregation of the Apostolic Sisters. These are weekly recordings that are commentaries to the Sunday Liturgy of the Word together with the Gospel content. The author of the recordings is a vocation psychopedagogue. She leads retreats, lectures and workshops [Facebook, 2021a]. She has been preparing podcasts since April 2021. The content transmitted in the podcasts is interesting and important. However, after listening, one can undoubtedly conclude that the recordings are not prepared in a professional recording studio. The editing along with the background music is of a reasonably good quality. The series can be listened to via platforms: Spotify, Apple Podcasts or Google Podcasts.

The podcast We Read the Whole Scripture is a series prepared by the author of the Langusta na palmie channel, Dominican Fr Adam Szustak. The podcasts contain excerpts from the Bible. They are released daily from 1 October 2020, and the project aims to present the whole of Scripture in recordings. "Let's read all of Scripture together! [...] Everyday 1 chapter of the life-giving WORD OF GOD!" [Apple Podcasts, 2021a] - exhorts Fr Adam Szustak in the series description. In a video on the YouTube channel, Fr Szustak promotes the action as follows: "I hope that while driving to work, or having a moment, you will listen to this one chapter. [...] And so every day, one chapter. I hope that as many of us as possible will read the Holy Scriptures. That would be great!" [YouTube, 2021a]. After listening to the excerpts of the series, one can notice that the recordings are prepared in good technical quality; the editing itself is also of a very good level. The layout of each podcast is the same - Fr Adam Szustak's reading of a chapter of Scripture enriched with issues in the form of questions left unanswered for your consideration. The series enjoys great interest and good opinion of the audience, especially young people. In their 
comments they point out, for example (original spelling): "This is exactly what I missed, Fr. Adam reads the Scriptures and comments briefly, as if to encourage further consideration :) Well, the best idea, just after 'Terrible Retreats', my absolute favourite! Great diction, radio voice, Scripture in a listening version, what more do you want? Thanks :)", "Super! Flawless diction + relevant, moving comments - what more do you want?" [Apple Podcasts, 2021a]. The series can be listened to via platforms: Spotify, Apple Podcasts, Google Podcasts and on the YouTube channel created by Fr Adam Szustak - Langusta na palmie.

The podcast Broken Histories is another series by Fr Adam Szustak "Broken Histories are stories about the daughters and sons of God, the beautiful and the ugly, the holy and the sinful, the happy and the on the verge of despair. They are stories about the road one takes to heaven and the twists and turns and cringes that push one to hell. They are stories about people simply. Which is to say, about us." [Apple Podcasts, 2021b] reads the series description. The podcasts appear weekly on Spotify, Apple Podcasts, Google Podcasts and the YouTube channel Langusta na palmie. The series presents stories sent by recipients of the channel run by Father Adam Szustak. The creator reads letters from listeners and gives commentary on faith, advice and guidance. The series enjoys very good reviews (original spelling): "I love it. Especially before bedtime, it calms you down, allows you to calm down. You can catch a lot of valuable advice. I don't know if it's a matter of Father or what..., but I feel more intimacy with God listening to these podcasts"; "I find them very engaging and they give me a wonderful strength to survive these difficult times." [Apple Podcasts, 2021b]. The podcasts are prepared to a very good standard in terms of recording quality, editing and musical setting.

The podcast Listen, Son, to the Master's Teachings... is a series of nearly 300 episodes of a podcast prepared by Father Konrad Małys of the Benedictine Abbey of Tyniec. The series is published every other day. It is a form of advice and life guidance in relation to the teachings and attitudes of St Benedict. "It is said of this Rule that it is characterized by an exceptional moderation: it finds the way to holiness not in the sharpness of ascetic practices, not in concentrating one's energies on this or that task in the Church, but in the harmonious combination of the fundamental practices of the Church's life, by means of which the Christian is no longer threatened with spiritual stagnation, but enters upon the path of constant growth in grace and love." [Apple Podcasts, 2021f] - reads the series description. The podcasts are recorded in good technical quality. The editing is also correct. The recordings are prepared without a soundtrack, but according to the author of this article it does not affect the reception of the podcast - the content itself is interesting enough without background music. The series enjoys good ratings from the audience e.g. (original spelling): "Thank you for these teachings! It's great that the podcast is back on this platform, thank you especially for the version that appeared in late 2019 and 2020 and I hope this one will be just as developmental and fascinating." [Apple Podcasts, 2021f]. The series can be listened to via: Spotify, Apple Podcasts, Google Podcasts.

The podcast After Familiarity is a series hosted by Fr Robert Hetzyg. As the creator of the podcast writes about himself: "I am a priest, a member of the Catholic community Koinonia Jan Chrzciciel. I am also involved in internet, press and radio journalism (now mostly podcasting). I have published in the Studio of Reportage and Documentary of the Polish Radio and on the website of Radio Wnet." [Apple Podcasts, 2021d]. So, as we can see, the clergyman is very strongly connected with the media and has a good journalistic technique. The format of the podcast resembles a radio show - you can listen to interviews, statements by the creator himself, as well as fragments of sermons. "Stories you want to share, conversations that bring people together and a Jesus worth listening to." [Apple Podcasts, 2021d]," reads the series description. The platforms through which the series can be listened to (Spotify, Apple Podcasts, Google Podcasts) lack audience comments. Also, an analysis of the fanpage dedicated to the series allows us to conclude 
that despite the appeal of the creator, there is no response from the audience. However, it should be emphasised that podcasts are prepared on a good technical level - both in terms of recording, editing and music. Perhaps, therefore, there is a lack of promotion of the series.

The podcast Mass21.Dominicans is a series consisting of sermons by Dominican priests (Fr Roman Bielecki and Fr Norbert Augustyn Lis) in mp3 form, recorded during Sunday Masses at 9pm - hence the name Mass21. A new episode appears on Spotify, Apple Podcasts, Google Podcasts every Sunday. What is missing here, however, is the relevant information about which church the sermons are recorded in. Only the analysis of the fanpage of the Mass21.Dominicans initiative allows us to state that the place where the recorded homilies are preached is the Dominican Monastery in Poznań. It can also be read here that the recorded sermons in the form of podcasts are a part of a larger initiative, the aim of which is to invite the faithful to participate in Holy Mass celebrated at 9 p.m. in the monastery mentioned above. On the fanpage, find numerous comments referring to the recorded sermons, such as (original spelling): "A wonderful sermon and guidance for us on how to live and fight our weaknesses! Thanks, Father Roman, every sermon stays with us longer and makes us reflect on ourselves!"; "Great sermon! Thank you"; "Thank you - I would listen more. Warm regards." [Facebook, 2021c] can be found. The comments show how important the content of the recordings for the recipients of the community gathered around the Mass21.Dominicans campaign is. The analysis of the recordings allows us to conclude that as far as the technical level of the recordings and editing is concerned, they are correct, but the quality could be more refined. The content of the comments, however, indicates that viewers focus on the essence of the message rather than the technical quality of the podcast series itself.

The Highlander Sermons podcast is another sermon series in the form of podcasts after Mszy21.Dominicans. The series is conducted by Father Wojciech Pal. The sermons are presented partly in the highlander dialect. The series is thus prepared in an unusual form, with the use of folk dialect. The content presented in the form of sermons is short, funny and original. Additionally, the reception is enriched by the musical setting of the recordings using the music of a highlander band. The quality of recording and editing itself is on a very good technical level. The series is available via such streaming services as Spotify, Apple Podcasts, Google Podcasts and on the website of the creator of the podcast: http://kazaniagoralskie.pl (in addition to the podcast, various other forms of expression are made available - e.g. prayer reflections in the form of online articles or poetry by the creator of the website) and the YouTube channel: https://www.youtube. com/channel/UCB_9OITIDiMkvjkJAVU9riA [YouTube, 2021b].

The podcast Listen to Hear is a series hosted by Piotr Żyłka - a journalist, blogger and book author. The podcasts appear once a month. They are published in the form of interviews. The description of the series reads: "I give voice to people who, for various reasons, find it increasingly difficult to find themselves in the Church. I look for answers to important questions about our community. I look for sensitivity and light. I invite you to walk a part of the way with me and with my interlocutors. With faith that something good and important will happen to us along the way." [Apple Podcasts, 2021e]. The interviews are very deep, insightful, emotional, extended (about 1.5 hours each), and always with a reference to faith. The series enjoys great interest and very good feedback from the audience. This is evidenced by comments on the creator's YouTube channel, e.g.: "Very interesting and informative talk", "How I was waiting for this podcast", "Very good interesting and orderly talk". [YouTube, 2021c]. The recordings are prepared in good technical quality, also concerning editing and musical setting. The series is available on platforms: Spotify, Apple Podcasts, Google Podcasts and on the journalist's website: http://piotrzylka.pl, as well as his YouTube channel: https://www.youtube.com/channel/ UCzIriT9umG933jE8U9POvjA [YouTube, 2021d].

Kindle your faith is a series of podcasts prepared by a lay charismatic and author 
of religious books Marcin Zielinski. The recordings are prepared in the form of interviews. "This series is full of inspiring stories, moving testimonies and content that I trust will strengthen your faith!" [YouTube, 2021e] - reads the description of the recordings. This is a relatively new series, appearing in the form of interviews. By August 2021, eight podcasts have been presented as part of the series. However, one inaccuracy is apparent here. Although the series description announces that recordings are published weekly, in practice new podcasts appeared on average twice a month, up to and including February 2021. Since then, only one has been released - the episode of 27 May 2021 [YouTube, 2021e]. Recordings are available on the YouTube channel (https://www.youtube.com/ channel/UCT67rkd2HTeHLfITX_D3LiQ), Spotify and the website run by Zielinski (https:// www.rozpalwiare.pl/).

\section{Conclusions}

The analysis of the selected ten Polish-language podcasts on the subject of faith allows us to answer the question about characteristics and content of the discussed podcasts on faith posed in the introduction. All presented series are available on audio platforms such as: Spotify, Apple Podcasts, Google Podcasts (very often podcasts are imported into other platforms via the free, easy-to-use, especially for novice audio form creators, platform Anchor [Google Play, 2021] or Spreaker [Spreaker, 2021]). Within the series presented, only one (Spread the Faith) limits itself to Spotify in terms of audio platforms. Half of the podcasts discussed are made available on the YouTube channel (including two series hosted by Fr Adam Szustak). Four cycles out of ten are placed on the creators' websites. As far as the content itself and the form of conveying faith topics are concerned, three out of ten (Praying on the Way, Listening with the Heart, Reading the Whole Scripture) contain reflections and commentaries on the Holy Scripture. Two of the discussed series are published in the form of sermons (Mass21.Dominicans, Kazania góralskie), three take the form of conversations, interviews concerning God, religious life, testimonies of conversions, etc. (After the acquaintance ${ }^{3}$, Listen to hear, Light up the faith). One of the podcasts (Stories Broken) are letters read by the creator of the recordings describing stories, while the series Listen, son, to the teachings of the master... is advice and life guidance in relation to the teachings and attitudes of St Benedict. All of the podcasts discussed, according to the author of this article, convey interesting, important religious content. The technical and editing quality of most of the analysed podcasts was assessed as high or very high. Only a few are prepared in a quality that requires considerable technical refinement (e.g. the Heart Listening series). However, it happens that the content of the series is so interesting that despite the shortcomings related to the technical quality of the sound, it "defends itself" (homily series Mass21.Dominican). Sometimes the shortcomings in the podcast concern the regularity of the appearance of the recording declared in the description. In most of the discussed series, the creators publish podcasts following the announced frequency, but there are also some (e.g. Kindle your faith), where this condition is not fulfilled. It is worth noting that most of the analysed podcasts are created by clergy persons (most often priests, monks - here Dominicans prevail). The recordings are prepared by clergymen usually in the form of reflections on the Word of God or commentaries to it, homilies or advice and tips related to religious life. Two of the discussed series are authored by laypeople (Piotr Żyłka, Marcin Zieliński), who are strongly involved in living the Catholic faith. Interestingly, these materials take the form of interviews, conversations. The creators of the presented podcasts often ask their audience for interaction and refer to their comments and statements.

Conclusions derived from the analysis made it possible to affirmatively answer the

Here, in addition to interviews, excerpts from the podcast creator's sermons and speeches are also published. 
main research question: Are podcasts on topics of faith a form of religious communication and why? This is undoubtedly supported by several issues:

1. The selected religious podcasts carry a message of faith (communication with or about the Absolute using mass media).

2. The form of faith transmission in the podcasts in question is interesting and modern, both regarding the format and, for the most part, the technical quality of the material; only a few examples of material need refinement.

3. The content covered in the podcasts is interesting and relevant to a faith-related audience.

4. The podcasts are produced by people who identify themselves with the Catholic Church, often associated with Church institutions or communities.

5. Faith podcasts are a form of interaction between people of faith - the viewers and creators of this content.

\section{Summary}

Polish language radio podcasts about faith are one of the forms of religious communication. They convey religious themes in an interesting and modern way; they are a tool for conveying the Gospel, teachings on topics close to the Catholic Church. The content concerning faith is presented in podcasts in good technical quality, only a few need to be refined in this context. The topic of the relation between podcasts and religious communication is worth further consideration, especially in terms of research on the reception of this form by listeners - e.g. how this reception affects their faith and whether there is anything that needs to be refined or improved in religious podcasts. The author of the article hopes that the study may be a contribution to further scientific research among scholars dealing with the theology of social media in Poland.

\section{References}

ADAMSKI A, JUPOWICZ-GINALSKA A, LEONOWICZ-BUKAŁA I. (2020), Polish Nationwide Catholic Opinion-Forming Weeklies on Social Media - From Theoretical Introduction to Empirical Approach, Religions 11 (4).

Apple Podcasts (2021a), We Read All of Scripture [online: 21 July 2021], https://podcasts.apple.com/us/podcast/czytamy-ca\%C5\%82e-pismo-\%C5\%9Bwi\%C4\%99te/

Apple Podcasts (2021b), Broken Stories [online: 21 July 2021], https://podcasts.apple.com/pl/podcast/historie-pot\%C5\%82uczone

Apple Podcasts (2021c), Highlander Sermons [online: 23 July 2021], https://podcasts.apple.com/pl/podcast/ kazania-goralskie/id1553004399?l=pl

Apple Podcasts (2021d), After the Familiar [online: 22 July 2021], https://podcasts.apple.com/pl/podcast/ po-znajomo\%C5\%9Bci

Apple Podcasts (2021e), Listening to hear [online: 23 July 2021], https://podcasts.apple.com/pl/podcast/s\%C5\%82ucha\%C4\%87-\%C5\%BCeby-us\%C5\%82ysze\%C4\%87

Apple Podcasts (2021f), Listen, son, to the teachings of the master [online: 22 July 2021], https://podcasts. apple.com/pl/podcast/s\%C5\%82uchaj-synu-nauk-mistrza

BENEDICT XVI (2010), Benedict XVI, Pope, Priest and pastoral ministry in a digital world: new media at the service of the Word. Message of Pope Benedict XVI for the 44th World Day of Social Communications, 2010. L'Osservatore Romano, 3(4): 6.

BONINI T. (2015), The 'Second Age' of Podcasting: Reframing Podcasting as a New Digital Mass Medium. Quaderns del CAC, 41(18): 21-30.

DOBEK-OSTROWSKA B. (ed.) (2007), Mass media around the world. Models of media systems and their development dynamics, Wrocław: Publishing House of the University of Wrocław.

DOLIWA U., CHYCZEWSKA A., GROBELSKI F., ŁATACZ R. (2019), Podcasting in Poland - an attempt to analyse the phenomenon. Media - Culture - Social Communication, 1(18): 37-54. 
Facebook (2021a), Anna Maria Pudełko AP [online: 20 July 2021], https://www.facebook.com/annamariaap Facebook (2021b), Praying on the Road [online: 20 July 2021], https://www.facebook.com/modlitwawdrodze Facebook (2021c), Mass21.Dominicans [online: 22 July 2021], https://www.facebook.com/Mass21.Dominicans Google play (2021), Anchor - create your own podcast [online: 28 July 2021], https://play.google.com/store/ apps/details?id=fm. anchor.android\&hl=pl\&gl=US

GAWROŃSKI S., MAJKOWSKA I. (2018). Marketing Communication of the Catholic Church-A Sign of the Times or Profanation of the Sacred? Studia Humana 7: 15-23.

GUZEK D. (2016). Catholic media in the Polish Media System. Toruń: Adam Marszałek Publishing House.

GUZEK D. (2019). The Church-State Relationship in Polish Media: Combining the Grounded Theory and Intermedia Agenda-Setting at the Network Level. Polish Sociological Review 208: 439-57.

JAKUBOWICZ K. (2011), New media ecology. Convergence and metamorphosis, Warsaw: Poltext.

JENKINS H. (2006), Convergence Culture. A collision of old and new media, Warsaw: Academic and Professional Publishing.

KIM J., KIM C. (2016), Perspectives to Understand the Relationship between Religion and Communication. Int J Journalism Mass Comm 3: 117.

LEŚNICZAK R. (2018), Category of identity and stereotype in religious communication. Próba hermeneutycznej interpretacji tekst prasowych tygodnika "Newsweek Polska" w kontekście obrad synodu o rodzin 2014-2015. Acta Universitatis Lodziensis. Folia Litteraria Polonica, 51: 87-88.

MAJCHRZYK $Ł$. (2020), The popularity of podcasts in Poland is growing at a dizzying pace! [online: 29 July 2021], https://mobirank.pl/2020/08/06/popularnosc-podcastow-w-polsce-rosnie-w-zawrotnym-tempie

MARCYŃSKI K. (2016a), Mobile applications as a new form of social and religious communication. University Sociological Journal, 15(2): 71.

MARCYŃSKI K. (2016b), Religious communication and media, Krakow: Petrus Publishing House.

MARKMAN K.M., SAWYER C.E. (2014), Why Pod? Further Explorations of the Motivations for Independent Podcasting. Journal of Radio and Audio Media, 21(1): 20-35.

Mmponline.pl (2019), Polish podcast boom [online: 27 July 2021], https://mmponline.pl/artykuly/230635,polski-boom-na-podcasty

MOBERG M. (2017), Church, Market, and Media: A Discursive Approach to Institutional Religious Change. London, Oxford, New York, New Delhi and Sydney: Bloomsbury Publishing.

Pontifical council for social communications (1992), Pastoral Instruction on Social Communications Aetatis novae, 22.02.1992. L'Osservatore Romano, ed. 6.

PASTWA R. J. (2020), Religious communication on the example of the Catholic Church in Poland considering the context of the coronavirus pandemic. Culture - Media - Theology, 41: 42.

PAWLIK A. (2012), Radio series on the Internet - audio art in the process of convergence, [in:] Z. Oniszczuk, M. Wielopolska-Szymura (ed.), Convergence of mass media and its consequences for contemporary journalism, vol. 1, University of Silesia, Katowice.

PODGÓRSKI I. (2021), What is a podcast? How do you launch your podcast? [Online: 20 July 2021], https:// www.igorpodgorski.pl/blog/co-to-jest-podcast

Press.pl (2021), Tandem Media: every third Internet user listens to podcasts regularly [online: 27 July 2021], https://www.press.pl/tresc/66260,tandem-media_-co-trzeci-internauta-slucha-regularnie-podcastow

Spreaker (2021), Create a podcast, [online: 10 August 2021], https://www.spreaker.com/create-a-podcast

STACHYRA G. (2017), Podcasting as an audio technology. Media Studies, 1(68): 29-41.

STACHYRA G. (2019), Podcasting in the perspective of the specificity of radio production. Media - Culture Social Communication, 4(12): 71-89.

TRIDENTE G., MASTROIANNI B. (2016), La missione digitale - Comunicazione della Chiesa e social media, Edizioni Santa Croce, Roma.

Youtube (2021a), We Read the Whole Bible and Make LIVE [online: 21 July 2021], https://www.youtube.com/ watch?v=6QG3SORLtIA

Youtube (2021b), Highlander Sermons xWojciechPal [online: 23 July 2021], https://www.youtube.com/channel/ UCB_90ITIDiMkvjkJAVU9riA

Youtube (2021c), Fr Tomasz Gaj - Dominican, psychologist and psychotherapist. We talk about the relationship between psychology and faith [online: 23 July 2021], https://www.youtube.com/watch?v=BJJjAMrD- 
VKQ\&list=PLIzEjmTgsznq5Ta-LLgAnGH7Z9r3R8e3h\&index=5\&t=17s

Youtube (2021d), Piotr Żyłka [online: 23 July 2021], https://www.youtube.com/channel/UCzlriT9umG933jE8U9POVJA

Youtube (2021e), Kindle your faith - podcast [online: 24 July 2021], https://www.youtube.com/watch?v=2CyaBGg-XeY\&list=PL-gA5Jv9ev2DHsh8nNDiiSw-k3pL5Z6VZ 